\title{
Antioxidant Activity of the Aqueous Crude Extract of Ocimum gratissimum LINN. Leaf on Basal and Cadmium-induced Serum Levels of Phosphatases in Male Guinea-pigs.
}

\author{
APRIOKU, J.S.; OBIANIME, A.W. \\ Department of Pharmacology, Faculty of Basic Medical Sciences. University of Port Harcourt \\ Email Address-sydaprio@yahoo.com.Phone No:08035082379
}

\begin{abstract}
The antioxidant activity of the aqueous crude extract of Ocimum gratissimum Linn. leaf on the basal and traumatized (cadmium-induced) serum levels of alkaline phosphatase (ALP), total acid phosphatase ( $\left.\mathrm{ACP}_{\mathrm{T}}\right)$ and prostatic acid phosphatase $\left(\mathrm{ACP}_{\mathrm{P}}\right)$ of the male guinea-pig (GP) were evaluated. Preliminary experimentation showed that the effects of the aqueous crude extract of $O$. gratissimum on basal serum phosphatases were slightly more in the oral than the intraperitoneal (i.p) route. Oral administration of $20 \mathrm{mg}$ of $O$. gratissimum caused a timedependent decrease in the basal serum levels of $\mathrm{ACP}_{\mathrm{T}}$ and $\mathrm{ACP}_{\mathrm{P}}$ without an effect on ALP values. The inhibitory effects compared to the control were maximum at 4 hours. Furthermore, O. gratissimum given orally, caused significant dose-dependent decreases $(\mathrm{p}<0.05)$ of the basal serum levels of $\mathrm{ACP}_{\mathrm{T}}$ and $\mathrm{ACP}_{\mathrm{P}}$ at $\mathrm{p}<0.05$. Basal serum concentrations of $\mathrm{ACP}_{\mathrm{T}}$ and $\mathrm{ACP}_{\mathrm{P}}$ changed from $23.50 \pm 1.04$ and $7.50 \pm 0.29$ to $8.25 \pm 0.75$ and $2.25 \pm 0.29 \mathrm{IU}$ at $20 \mathrm{mg}$, representing 65 and $70 \%$ decreases respectively. In contrast, $0.25-8 \mathrm{mg} / \mathrm{kg}$ of cadmium $(\mathrm{Cd})$ given intraperitoneally, caused significant dose-dependent increases $(\mathrm{p}<0.05)$ in the phosphatase enzymes. However pretreatment with $5 \mathrm{mg}$ of the crude extract, which on its own had little effect on basal serum phosphatase levels, followed by i.p administration of $\mathrm{Cd}$, caused a reversal of the $\mathrm{Cd}$-induced dose-response curves on the various phosphatase levels to negative values. These results may be due to the oxidative and the antioxidative biochemical antagonistic properties of the agents used in these experiments. They may also be due to enzyme conformational changes and effects of eugenols and flavonoids in the crude extract of O. gratissimum. @ JASEM
\end{abstract}

Oxidation is an essential process in all organisms which involves redox reactions. These reactions normally generate reactive oxygen species (ROS) or highly reactive free radicals that can react virtually with all cell components to cause tissue injury (Collier et al., 1992). Exogenous sources of free radicals include tobacco smoke, ionization radiation, certain pollutants such as cadmium, vanadium, crude oil, organic solvents and pesticides (Robinson et al., 1997). The resulting oxidative free radicals are obligate intermediates of many metabolic reactions but may also cause pathological damage (Floyd et al., 1990). Similarly, antioxidation is the reversal of the above described processes mediated through scavenging of the free radicals, by dismutase enzyme systems, and phenolic-rich compounds such as flavonoids (Sardesai 1995; Rice-Evans et al., 1996). The body has evolved a number of interrelated antioxidant mechanisms to maintain redox homeostasis (Toyokuni et al., 1999). These antioxidant mechanisms include antioxidant enzymes: superoxide dismutase (SOD), catalase (CAT), gluthathione peroxidase (GSH-Px), heme oygenase (HO) etc (Ames et al., 1993; Sardesai 1995; Sies, 1997; Vertuani et al., 2004). A disturbance in the balance between the production of reactive oxygen species or free radicals and antioxidant defense, which may lead to tissue injury, is termed 'Oxidative Stress'. Ocimum gratissimum Linn. locally referred to as "Scent Leaf", is a vegetable commonly used as a spice in its unprocessed form in most West African and Nigerian dishes because of its very intense and dominant flavour of cloves (Odukoya et al., 2005). It is also an antioxidant (Odukoya et al., 2005; Leal et al., 2006; Afolabi et al., 2007) with volatile oils which contain phenolic-eugenols, thymol, flavonoids, phenylpropanoids, linalool, citral etc as pharmacologically active agents (Jedlickova et al., 1992; Leal et al., 2006). These active agents confer on it its anti-oxidative, chemotherapeutic, antispasmodic and analgesic actions (Ilori et al., 1996; Nakamura et al., 1999; Aziba et al., 1999; Rabelo et al., 2003). Most of the studies/investigations carried out with $O$. gratissimum did not show a qualitative (dose-andtime-dependent) effect of the agent. Furthermore, none of the studies reveal whether this agent will inhibit both basal and traumatized levels of phosphatases in the body's pathology. It is therefore in that light that we seek to answer these questions in this study, using cadmium to induce oxidative stress by stimulating serum phosphatase activities.

\section{MATERIALS AND METHODS MATERIALS}

Electrical centrifuge (Hamilton Bell Co Inc, Montvale NJ); analytical weighing balance, atomic mass spectrophotometer (Humalyzer Junor, Human $\mathrm{GmBH}$ ); incubator (Phillip Harris Ltd, England); fresh $O$. gratissimum L. leaves; test tubes; dissecting sets, pipettes, oral canular; sterile injection needles and syringes; sterile specimen bottles.

Chemicals: Absolute alcohol (BDH Chemicals Ltd, England); Urethane m.p $47^{\circ} \mathrm{C}-50^{\circ} \mathrm{C}$ (BDH Chemicals Ltd, England,); $40 \%$ formalin (M\&B, England);

\footnotetext{
* Corresponding author: Aprioku, J.S.
} 
Cadmium Chloride 99.5\% (Chadwell Heath Essex, England); commercially available Alkaline Phosphatase test kit (QCA, S.A, Amposta / Spain); Acid Phosphatase test kit (Randox Lab Ltd, UK); distilled water (obtained from the Department of Chemistry, University of Port Harcourt, Nigeria); all other chemicals were of analar grades.

Animals: Adult male guinea-pigs of average weight $450 \pm 5 \mathrm{~g}$ were obtained from the animal house in the University of Port Harcourt, Nigeria and allowed to acclimatize for 14 days. The guinea-pigs were fed with fresh elephant grass daily ad libitum at a room temperature of $22^{\circ} \mathrm{C}$ with 12 -hr light/dark cycle.

\section{METHODS}

Extraction of Ocimum gratissimum (Lamiaceae) Linn. leaf: The plant, $O$. gratissimum L. was identified by a senior botanist in the botanical garden of the University of Port Harcourt and some fresh leaves were collected, and dried in an oven at $60^{\circ} \mathrm{C}$ to a constant weight and ground to fine powder. Forty grams $(40 \mathrm{~g})$ weight of the powdered herb was added to $400 \mathrm{ml}$ of boiling distilled water and allowed to boil for five minutes. The mixture was allowed to cool for 45 minutes and filtered to obtain a solution of $200 \mathrm{mg} / \mathrm{ml}$ of the crude extract. The extract was stored in the refrigerator at $4^{0} \mathrm{C}$ and used for the experiments.

Effects of the aqueous crude extracts of Ocimum gratissimum $L$. leaf on basal serum phosphatase levels of the male GP through different routes of administration: In this study, twenty (20) adult male GPs were divided into four groups (A, B, C and D) of five animals each. The animals in group A were given $20 \mathrm{mg}$ of $O$. gratissimum crude extracts orally and those in group B (serving as control) were orally administered with distilled water. Furthermore, the animals in group $\mathrm{C}$ were given $20 \mathrm{mg}$ of the aqueous crude extract of $O$. gratissimum intraperitoneally, while animals in the last group D (which were used as control for the i.p study) were administered with distilled water through the i.p route. At the end of four hours, the animals were anaesthetized with $25 \%$ urethane solution at a dose of $6 \mathrm{ml} / \mathrm{kg}$ and dissected carefully to collect blood samples through the major artery and the heart to analyze serum levels of ALP, $\mathrm{ACP}_{\mathrm{T}}$ and $\mathrm{ACP}_{\mathrm{P}}$ using commercially available kits from Randox Laboratories Ltd, Uk and QCA, Spain.

Time-dependent effect of the aqueous crude extracts of $O$. gratissimum $L$. leaf on basal serum phosphatase level: In $n=40$ animals, adult male guinea-pigs were divided into 7 groups and a control group of five animals each. While the control animals were orally administered with distilled water, the test animals were given $20 \mathrm{mg}$ of aqueous crude $O$. gratissimum L. extract orally and observed over 0.5 , $1,2,4,8,18$, and 24 hours. The blood samples were respectively collected later for biochemical assay.

Dose-dependent effects of the aqueous crude extract of $O$. gratissimum $L$. leaf on basal serum phosphatase level: In $\mathrm{n}=40$ animals, guinea-pigs were orally administered with the crude aqueous extract of $O$. gratissimum $\mathrm{L}$. in the dose range of 5$320 \mathrm{mg}$. Blood was then collected 4 hours later and analyzed to measure the serum levels of ALP, $\mathrm{ACP}_{\mathrm{T}}$, and $\mathrm{ACP}_{\mathrm{P}}$ as above.

Effects of cadmium on basal serum phosphatase levels of the male GP: In $n=35$ animals, guinea-pigs were divided into seven groups of five each and were administered single doses of $0,0.25,0.5,1,2,4$, and $8 \mathrm{mg} / \mathrm{kg}$ of cadmium as $\mathrm{CdCl}_{2}$ intraperitoneally. After 24 hours, blood samples were collected and analyzed for $\mathrm{ALP}, \mathrm{ACP}_{\mathrm{T}}$ and $\mathrm{ACP}_{\mathrm{P}}$.

The effects of $O$. gratissimum pretreatments on Cd-induced phosphatase serum levels: In $n=35$ animals, guinea-pigs were divided into seven (7) groups of five animals each and pretreated with $5 \mathrm{mg}$ of $O$. gratissimum L., given orally for four hours, before administering $0.25,0.5,1,2,4$, and $8 \mathrm{mg} / \mathrm{kg}$ of $\mathrm{Cd}$ intraperitoneally. Blood samples were also collected and analyzed for $\mathrm{ALP}, \mathrm{ACP}_{\mathrm{T}}$ and $\mathrm{ACP}_{\mathrm{P}}$ after 24 hours as above.

Blood Enzyme Assays: Sample serum was separated from the cells, centrifuged at 3400r for 10 minutes and used for the assays. Serum alkaline phosphatase was assayed using the phenolphthalein method (Babson et al., 1966), while the colourimetric method was used to assay total and prostatic acid phosphatases (Fishman and Davidson, 2006)

Statistical Analysis: Data were expressed as means \pm standard errors of mean. Comparisons between control and treated groups of guinea-pigs were performed with one-way analysis of variance (ANOVA), followed by Duncan's multiple comparison test. Statistical significance was set at $\mathrm{p}<0.05$.

\section{RESULTS AND DISCUSSION}

In this study, the effects of $O$. gratissimum on the basal and traumatized (cadmium-induced) serum phosphatase $\left(\mathrm{ALP}, \mathrm{ACP}_{\mathrm{T}}\right.$ and $\left.\mathrm{ACP}_{\mathrm{P}}\right)$ levels in male guinea-pigs were investigated. Also investigated were the dose- and-time-dependent effects of the crude extracts of $O$. gratissimum on basal phosphatase levels. In $n=20$, preliminary experiment in this study, the activity of the aqueous crude extract was observed to be dependent on the route of 
administration. $20 \mathrm{mg}$ of the aqueous crude extract of $O$. gratissimum given through the oral and intraperitoneal routes over 4 hours showed that oral administration of $O$. gratissimum caused slightly higher levels of $\mathrm{ACP}_{\mathrm{T}}$ and $\mathrm{ACP}_{\mathrm{P}}$ inhibitions (Fig. 1a). Thus, the oral route was used in all subsequent investigations. Time-based studies also showed that $O$. gratissimum caused time-dependent effects on basal serum phosphatase levels (Fig. 2a). In this study, using a single dose of $O$. gratissimum $(20 \mathrm{mg}$ ), the basal concentrations of $\mathrm{ACP}_{\mathrm{T}}$ and $\mathrm{ACP}_{\mathrm{P}}$ were decreased sharply from $22.50 \pm 1.04$ and $7.25 \pm 0.25$ to $18.75 \pm 1.94$ and $6.50 \pm 0.29$ units $(25.6 \%$ and $41.4 \%$ decreases) respectively in the first hour, maximizing at the fourth hour (Fig. 2a). In the dose-response study, O. gratissimum caused significant decreases $(p<0.05)$ in the basal serum levels of $\mathrm{ACP}_{\mathrm{T}}$ and $\mathrm{ACP}_{\mathrm{P}}$ over the dose-range of $0.5-20 \mathrm{mg}$, with little or no effect on ALP (Fig. 2b). The maximal decrease in basal values was obtained at $20 \mathrm{mg}$ of the crude extract, decreasing basal serum levels of $\mathrm{ACP}_{\mathrm{T}}$ and $\mathrm{ACP}_{\mathrm{P}}$ from $24.50 \pm 1.04$ and $6.50 \pm 0.29$ to $9.75 \pm 1.25$ and $2.50 \pm 0.29$ units (60.20 and $61.54 \%$ decreases) respectively. However, further increases in the dose of $O$. gratissimum from $20-320 \mathrm{mg}$ caused a reversal of these effects (Fig 2b).

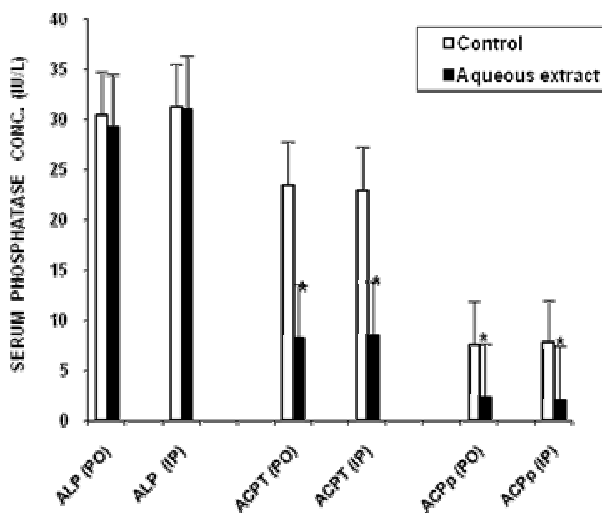

Fig. 1. The effects of aqueous crude extract of O.gratissimum on basal serum phosphatase levels of the male GP through different routes- (PO- oral and IP- intraperitoneal). Data are mean $\pm \mathrm{SEM}, \mathrm{n}=5$. *Treated GPs significantly different from control GPs at $\mathrm{P}<0.05$ ANOVA.
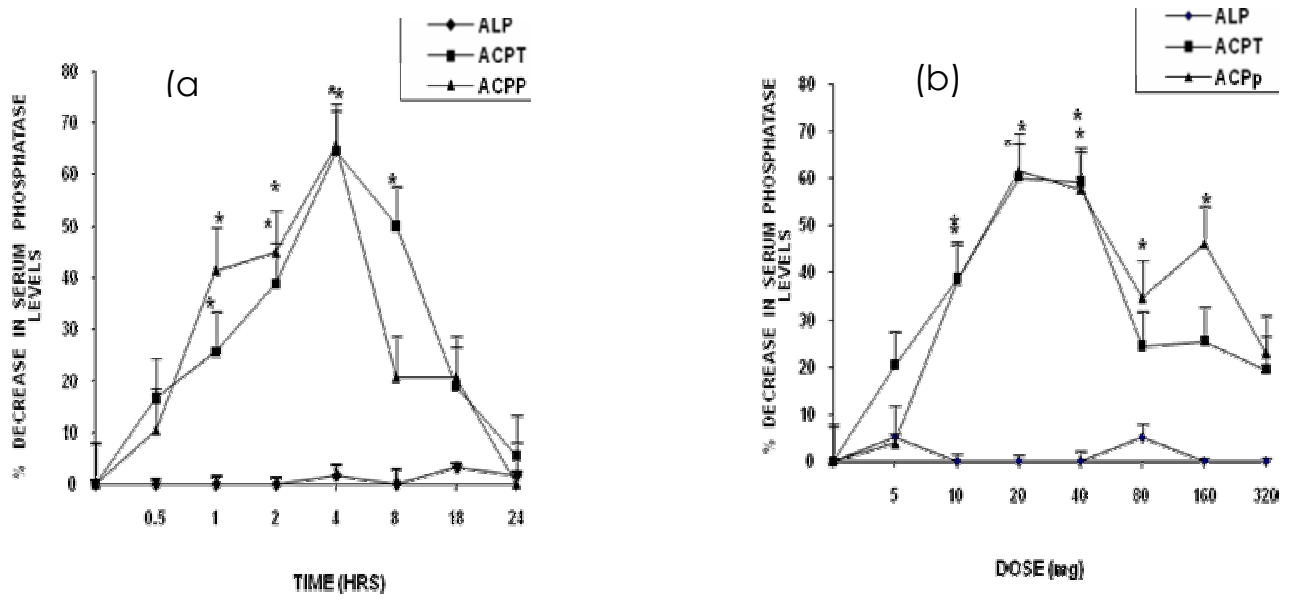

Fig. 2. Graphs showing (a)- Time-dependent and (b)- Dose-dependent (0.5-320mg) effects of O. gratissimum on the serum phosphatase levels of the male GP, (represented as \% decrease). Data are mean \pm SEM, $n=5$. *Treated GPs significantly different from control GPs at $\mathrm{p}<0.05$ ANOVA.

In contrast, $\mathrm{Cd}$ over the dose range of $0.25-8 \mathrm{mg} / \mathrm{kg}$ caused significant dose-dependent increases $(\mathrm{P}<0.05)$ in the basal serum phosphatases (Fig. 3). Maximal effects were observed at $2 \mathrm{mg} / \mathrm{kg}$ of cadmium causing 77, 85 and $71 \%$ increases in ALP, $\mathrm{ACP}_{\mathrm{T}}$ and $\mathrm{ACP}_{\mathrm{P}}$ respectively (Fig. 3). The actual serum values obtained for ALP, $\mathrm{ACP}_{\mathrm{T}}$ and $\mathrm{ACP}_{\mathrm{P}}$ were $54.00 \pm 2.16$,
$40.75 \pm 2.93$ and $12.00 \pm 1.08$ units, compared to baseline values of $30.50 \pm 0.65,22.00 \pm 0.71$ and $7.00 \pm 0.41$ to $33.75 \pm 1.31,23.00 \pm 0.71$ and $7.75 \pm 0.25$ units respectively. Oral pretreatment of the animals with $5 \mathrm{mg}$ of $O$. gratissimum, with subsequent intraperitoneal administration of $\mathrm{Cd}$ reversed the effects of $\mathrm{Cd}$ on basal serum phosphatase levels, 
causing the dose-response curves of $\mathrm{Cd}$ to have negative values (Figs. $4 \mathrm{a}, \mathrm{b}$ and $\mathrm{c}$ ). $O$. gratissimum $(5 \mathrm{mg})$ caused a very significant inhibition $(\mathrm{P}<0.05)$ of cadmium's activity on phosphatase enzymes, by decreasing Cd-induced levels of ALP, $\mathrm{ACP}_{\mathrm{T}}$ and $\mathrm{ACP}_{\mathrm{P}}$ from $54.00 \pm 2.16,40.75 \pm 2.93$ and $12.00 \pm 1.08$ to $30.25 \pm 2.56,11.75 \pm 1.65$ and $4.25 \pm 0.25$ units respectively at $2 \mathrm{mg} / \mathrm{kg}$. These values were less than the control basal serum levels, hence causing negative \% increases: $-0.82 \%,-46.59$ and 39.29 respectively (Figs. $4 a, b$ and c).

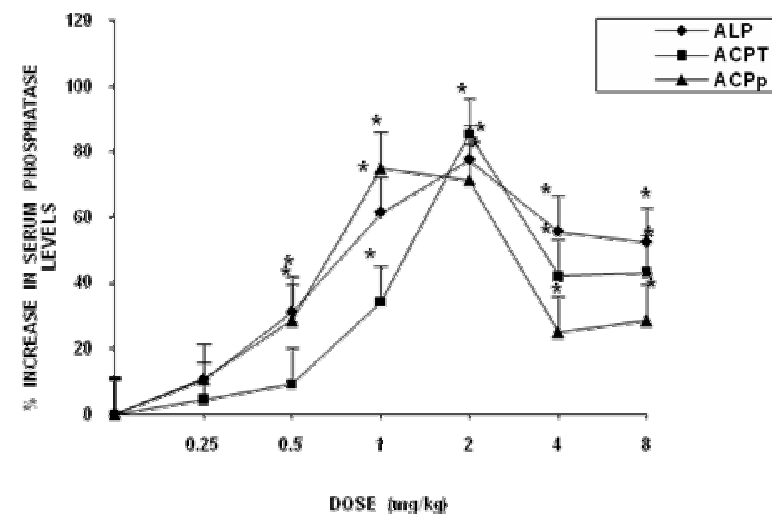

Fig. 3. The dose-dependent effects of cadmium on the serum phosphatase levels of male GPs. Data are mean \pm SEM, $n=5$. *Treated GPs significant different from control GPs at $\mathrm{P}<0.05$ ANOVA.
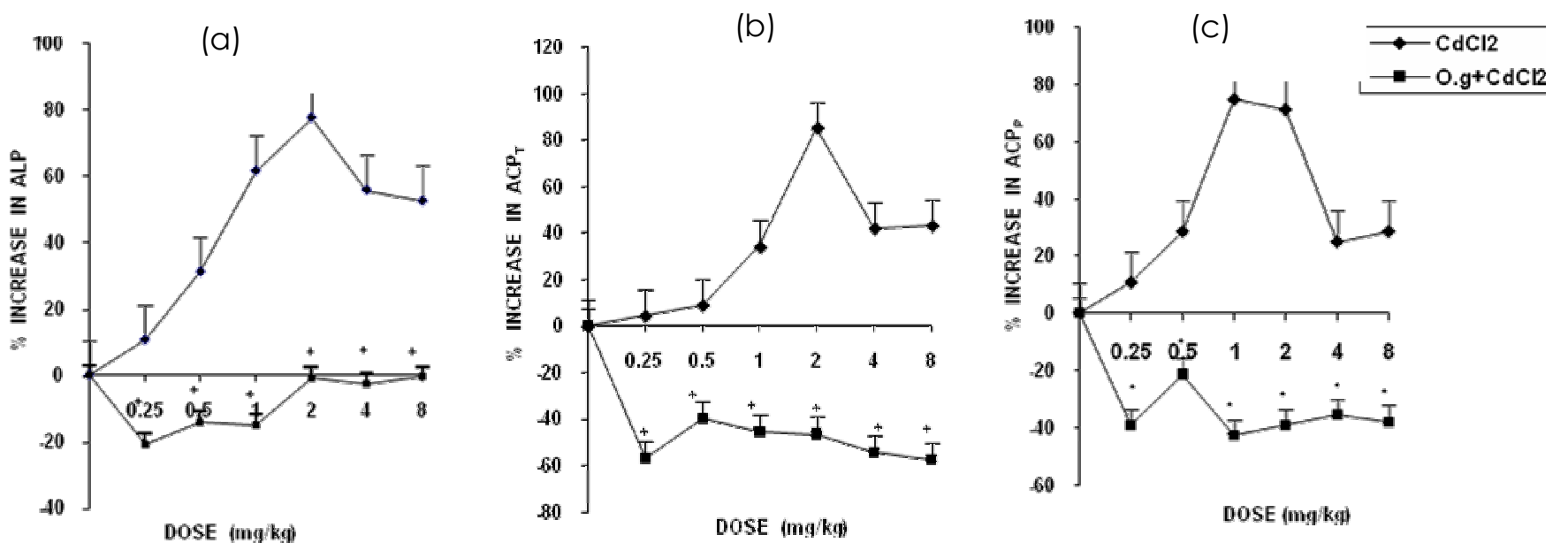

Fig. 4. The effects of $O$. gratissimum pretreatment on Cd-induced increases in serum phosphatase levels of male the GP (a- ALP; b- ACP and $\mathrm{c}-\mathrm{ACP}_{\mathrm{T}}$ ). Data are mean $\pm \mathrm{SEM}, \mathrm{n}=5$; ${ }^{+}$Pretreated GPs significantly different from Cd-treated GPs at $\mathrm{P}<0.05$ ANOVA

The antioxidant activity (AA) of $O$. gratissimum has been assessed using various assay techniques, including the coupled reaction of beta-carotenoid linoleic acid (Leal et al., 2006); ferric thiocyanate method (Odukoya et al., 2003) DPPH scavenging activity (Afolabi et al., 2007) and reducing power assay (Odukoya et al., 2005; Afolabi et al., 2007). In this study, the effects of $O$. gratissimum on basal serum phosphatases and under traumatized or raised tones were evaluated to assess its AA. Phosphatase enzymes are produced by various organs of the body, but mainly in the liver, testis and the prostate gland. The serum activity of an intracellular enzyme rises as it is released from the damaged cells that contain it.
Increase in the levels of serum phosphatase enzymes and other hepatic enzymes such as alanine aminotransferase (ALA), aspartate aminotranferase (APT) and sorbitol dehydrogenase (SDH) are good indicators of oxidative stress in several studies (Habeebu et al., 2000; Obianime and Aprioku, 2008), which also indicates possible damage of the affected tissues. Phosphatases can therefore be considered as oxidative enzymes, which are stimulated under oxidative stress. Oxidative stress results from the generation of oxidative free radicals during normal or abnormal metabolic processes, which are capable of causing damage to cellular components of the body. In this study, $O$. gratissimum caused a significant 
dose-dependent decrease $(\mathrm{P}<0.05)$ in the basal serum levels of $\mathrm{ACP}_{\mathrm{T}}$ and $\mathrm{ACP}_{\mathrm{P}}$, causing about 64 and $66 \%$ decreases in their activities respectively at $20 \mathrm{mg}$. This result indicates that $O$. gratissimum inhibits the oxidative phosphatase enzyme activity, and can therefore prevent oxidative stress/damage that could occur during normal metabolic processes. In contrast, in this study, cadmium $(0.25-8 \mathrm{mg} / \mathrm{kg})$ caused a significant dose-dependent increase $(\mathrm{P}<0.05)$ in the basal serum levels of $\mathrm{ALP}, \mathrm{ACP}_{\mathrm{T}}$ and $\mathrm{ACP}_{\mathrm{P}}$, thus inducing oxidative stress, which is consistent with previous works on Cd (Ikediobi et al., 2004; Kara et al., 2005, Obianime and Aprioku, 2008). The elevated levels of these are excellent indicators of Cd-induced hepatocellular, testicular and prostate damages (Jeong et al., 2000; Robert et al., 2002; Gary and Michael, 2002) through the generation of reactive oxygen species (ROS) especially $\mathrm{H}_{2} \mathrm{O}_{2}$ and $\mathrm{O}_{2}^{-}$and oxidative damage to the protective antioxidant enzymes including Superoxide Dismutase (SOD), Glutathione Reductase (GR) and Glutathione Peroxidase (GPx) in the body (Ikediobi et al., 2004). Furthermore, the increase in the serum phosphatase levels is attributed to leakages from the membrane joining the binary canalicules and the sinusoidal border of parenchyma cells of these tissues/organs into the blood due to Cd-induced damage to their cell membranes (Gary and Michael, 2002). In this study, Cd-induced levels of serum phosphatases were reversed by $O$. gratissimum. It also showed that the inhibitions were independent of the dose of $\mathrm{Cd}$, shifting the dose-response curves of $\mathrm{Cd}$ to the right and decreasing the maximum. This suggests that $O$. gratissimum non-competitively blocked the effects of $\mathrm{Cd}$. This may be due to its inhibitory effects on some molecular mechanisms resulting in the inhibition of $\mathrm{Ca}^{2+}$ metabolism and utility. In this study, it has been shown that $O$. gratissimum decreases both basal and raised serum levels of oxidative phosphatase enzymes. Previous studies have reported that $O$. gratissimum L. has antioxidant properties (Afolabi et al., 2007) but no work has reported on its effect on basal and traumatized oxidative states, which makes this work novel and useful. Oxidative stress has been implicated in the etiology of a large number of human conditions including atherosclerosis (Haffner, 2000; Baynes and Thorpe 2000; Jialal and Devaraj, 2003), type II diabetes mellitus (Lipinski, 2001), rheumathoid arthritis (Blake et al., 1994), long-term neurodegenerative diseases and pancreatitis (Spector, 1995). O. gratissimum may be protective in these clinically- and environmentally-induced pathological conditions.

\section{Acknowledgement}

We are grateful to the laboratory staff of the Department of Pharmacology in University of Port
Harcourt for their technical assistance. We also thank Mr. Maxwell Azubuike of the Department of Mathematics/Statistics, University of Port Harcourt, for his skillful assistance in the statistical analysis.

\section{REFERENCES}

Afolabi, C; Akinmoladun, EO; Ibukun, EA; Obuotor, EM; Farombi, EO (2007). Phytochemical constituent and antioxidant activity of extract from the leaves of $O$. gratissimum, Scientific Research and Essay. 2 (5); 163-166

Ahmed, RG (2005). Is There A Balance Between Oxidative Stress And Antioxidant Defense System During Development? Med J of Islamic World Academy of Sciences. 15(2);55-63.

Akinyemi, KO; Oladapo, O; Okwara, CE; Ibe, CC; Fasure KA (2005). Screening of crude extracts of six medicinal plants used in South-West Nigerian unorthodox medicine for antimethicillin resistant Staphylococcus aureus activity. BMC Complement Altern Med. 5; 6.

Ames, BN; Shigenaga, MK; Hagen, TM (1993). Oxidants, antioxidants and the degenerative diseases of aging. Proc Natl Acad Sci, U.S.A. 90; 7915-7922

Aziba, PI; Bass, D; Elegbe, Y (1999). Pharmacological investigation of Ocimum gratissimum in rodents: Phytotherapy Research. 13(5); $427-429$.

Babson, LA; Greeley, SJ; Coleman, CM; Phillips, GD (1966). Phenolphthalein Monophosphate as a Substrate for Serum Alkaline Phosphatase. Clin. Chem. 12; 482- 490

Baynes, TW; Thorpe, SR (2000). Glycoxidation an lipoxidation in atherogenesis. Free Radic Biol Med. 28; 1708-1716.

Blake, DR; Winyard, PG; Marok, R (1994). The contribution of hypoxia-reperfusion injury to inflammatory synovitis: the influence of reactive oxygen intermediates on the transcriptional control of inflammation. Ann N Y Acad Sci. $723 ; 308-317$

Collier, A; Rumiey, A; Rumley, AG; John, RP; John, PL; Gordon, DO; Micheal, S (1992). Free radical activity and hemostatic factors in NIDDM patients with and without microalbuminuria. Diabetes. 41; 909-913. 
Fishman, HW; Davidson, MH (2006). Determination of Serum Acid Phosphatases Method Biochemical Analysis. 4; 257-284.

FIoyd, RA (1990). Role of oxygen free radicals in carcinogenesis \& brain ischemia.FASEB J. 4; $2587-97$

Gary, MW; Michael JL (2002). Alteration of Liver Cell Function and Proliferation: Differentiation between Adaptation and Toxicity. In: Taylor S, Francis D, eds. Toxicologic Pathology. 2nd ed. London, PA: Elsevier; 41

Habeebu, SS; Liu, J; Liu, Y; Klaassen, CD (2000). Metallothionein null mice are more sensitive than wild-type mice to liver injury induced by repeated exposure to Cd. Toxicol. Sci.55,223232.

Haffner, SM (2000). Clinical relevance of oxidative stress concept. Metabolism. 49; 30-34.

Ikediobi, OC; Badisa, LV; Ayuk-Takem, TL; Latinwo, ML; West, J (2004). Response of antioxidant enzymes and redox metabolites to cadmium-induced oxidative stress in CRL-1439 normal rat liver cells, International Journal of Molecular Medicine. 14; 87-92.

Ilori, M; Sheteolu, AO; Omonigbehin, EA; Adeneye, AA (1996). Antidiarrhoeal activities of Ocimum gratissimum (Lamiaceae). J Diarrhoeal Dis Res. 14 (4); 283-5.

Jedlicková, Z; Mottl, O; Serý, V (1992). Antibacterial properties of the Vietnamese cajeput oil and ocimum oil in combination with antibacterial agents. J. Hyg Epidemiol Microbiol Immunol. 36(3); 303-9.

Jialal, I; Devaraj, S (2003). Antioxidants and atheorosclerosis: don't throw out the baby with the bath water. Circulation. 107; 926-8.

Jeong, S; Habeebu, SS; Klaassen, CD (2000). Cadmium decreases gap junctional intercellular communication in mouse liver. Toxicological Sci. $57 ; 156-166$
Kara, H; Karatas, F; Canatan, H; Serv, K (2005). Effects of exogenous metallothionein on acute cadmium toxicity in rats. Biological Trace Element Research. 104(3); 223-232

Leal, PF; Chaves, F; Celio, M; Ming, LC; Petenate, AJ; Meireles, M; Angela, A (2006). Global yeilds, chemical composotions and antioxidant activities of Clove basil (O. gratissimum L.) J. of Food Process Engineering. 29(5); 547-559

Lipinski, B (2001). Pathophysiology of oxidative stress in diabetes mellitus. J Diabetes Complications. 15; 203-210.

Nakamura, VC; Ueda-Nakamura, T; Bando, E; Melo, AFN; Cortez, DAG; Filho, PDB (1999). Antibacterial Activity of Ocimum gratissimum L. Essential Oil, Memorias do Instituto Oswaldo Cruz. 94(5); 675-678.

Obianine, AW; Aprioku, JS (2008). Ocimum gratissimum Linn. reverses cadmium-induced toxicity in the testicular structure and function of the male guinea-pig. West African Soc. for Pharmacol Book of Abstracts. ETP11, 17.

Oduksoya, AO; Ilori, OO; Sofidiya, MO; Aniunoh, OA; Lawal, BM; Tade, IO (2005). Antioxidant activity of Nigerian dietary spices; EJEAFChe. 4 (6); 1086-1093

Rabelo, M; Souza, EP; Soares, PMG; Miranda, AV; Matos, FJA; Criddle, DN (2003). Antinociceptive properties of the essential oil of Ocimum gratissimumI L. (Labiatae) in ice. Bra. J. Med. Biol. Res. 36;521-524.

Rice-Evans, CA; Miller, NJ; Paganga, G (1996). Structure-antioxidant activity relationships of flavonoids and phenolic acids Free Radical Biol. Med. 20; 933-956

Robert, KK; Michael, PW; Peter, L; Ben, L; Robert, SM; Glenn, SI (2002). Differential Hepatotoxicity Induced by Cadmium in Fischer 344 and Sprague-Dawley Rats. Toxicol. Sci. 65 (1); 151-59 
Robinson, EE; Maxwell, SRJ; Thorpe, GHG (1997). Free Rad. Res. 26; 291-302.

Sardesai, VM (1995). Role of antioxidants in health maintenance. Nutr Clin Pract. 10; 19-25, 1995.

Sies, H (1997). "Oxidative stress: oxidants and antioxidants". Exp Physiol. 82 (2); 291-5.

Somchit, MN; Reezal, I; Nur, EI; Mutalib, RR (2003). In vitro antimicrobial activity of ethanol \& water extracts of Cassia alata. J. of ethnopharmacology. 84(1); 1-4.
Spector, A (1995). Oxidative stress-induced cataract: mechanism of action. FASEB J. 9;1173-1182.

Toyokuni, S (1999). Reactive oxygen speciesinduced molecular damage and its application in pathology. Pathol Int. 49; 91-102.

Vertuani, S; Angusti, A; Manfredini, S (2004). "The antioxidants and proantioxidants network: an overview". Curr Pharm Des. 10 (14); 1677-94. 